\title{
FACTORS INFLUENCING THE DEPLOYMENT OF INNOVATIVE (ICT) FACILITIES BY CONSTRUCTION ORGANISATIONS IN PORT HARCOURT, NIGERIA
}

Hafex Ikemefuna Onyejeakor River State University, Nigeria E-mail: hafexikem@gmail.com

Emmanuel Chidiebere Eze Federal University Of Technology Owerri, Nigeria E-mail: emmanueleze001@gmail.com

Onyealilam Peter Onyeagam Federal Polytechnic Nasarawa, Nigeria E-mail: ponyeagam@yahoo.com

Adesoji Anthony Adegboyega Waziri Umaru Federal Polytechnic Brinin Kebbi, Nigeria E-mail: adegboyegaadesoji@gmail.com

Submission: 7/10/2019 Revision: 9/18/2019 Accept: 10/2/2019

\section{ABSTRACT}

Data management and exchange of information within contractor organization or between contractors and/or consultant or clients are facilitated through effective information and communication technologies (ICTs) facility provisions. Information exchange happens in real time and jobs made easier through the use of electronic devices. In spite of the huge data generation and information exchange needs of construction contractors, they are still faced with the challenge of adopting ICT in their daily transactions. Thus, this research set out to assess the factors influencing innovative ICT facilities deployment in contracting firms in Port Harcourt. The study adopted a survey approach, in which quantitative data were gathered from construction professionals within the study area, using of a well-structured questionnaire. With a response rate of $68.28 \%$, the data gathered were analyzed using percentage and factor analysis. The study reveals that the factors influencing the deployment of ICT in construction are; Change related issues, Security related concerns, Human and 
DOI: 10.14807/ijmp.v11i4.1096

management related Concerns, and Cost related Concerns. Key among these factors are satisfaction with existing method of working, inadequate trained ICT professionals, inadequate knowledge about return on ICT investment, virus attack, security breach and fear of piracy, and lack of legal support for use of ICT. It was recommended that government should put legislation in place to make it mandatory for construction firms to make ICT an integral part of their service delivery.

Keywords: Construction firms, Factors analysis, ICT Deployment, Information and Communication Technology, Port Harcourt, Nigeria

\section{INTRODUCTION}

Construction industry is the prime mover and the main stay of nations. The industry is adjudged as an influential sector that provide job and stimulate growth in the economy (ONYEAGAM et al., 2019). Thus, it is known as a great influencer and accelerator of national growth and development. However, the construction industry has been criticized for their poor productivity, inefficiency and poor quality performance of product delivery (SEKUO, 2012). The contractor who is one of the major stakeholders in construction contracts have been blamed for this abysmal performance situation. This is because the contractors are the constructors of the construction work and their performance has often times been used to rate the success of construction projects.

Poor performance in areas of communication and information exchange amongst the parties to a construction contract has been blamed as a major contributor to this issue. According to SEKOU (2012), one of the central issues contributing to the construction industry's poor performance is ineffective communication and exchange of information and data amongst the project team. Similarly, as reported by LOFGREN (2006), a larger part of the production problems in the construction industry is strongly related to the communication and information exchange amongst the parties involved in construction projects.

Construction project consist of processes; a process consist of series of actions and tasks which lead to certain goals (ONYEAGAM et al., 2019). According to Maqsood et al. (2004), on a daily basis, these construction processes demand heavy exchange of data and information between project participants. Thus, the construction industry is an information-intensive industry, that requires close coordination among a large number of specialized but inter-reliant organizations and individuals to achieve the cost, time and quality goals of a construction project (TOOLE, 2003). 
DOI: 10.14807/ijmp.v11i4.1096

ICT has been shown to be a vital tool in assisting the construction industry to cope with the increasing complexity of its products as well as the increasing demands of its clients and regulators (BETTS, 1999), and to enhance construction productivity (LISTON et al., 2000).

Alaghbandrad et al. (2011) maintain that Information and Communication Technology (ICT) is a crucial aspect of technology that covers any product that will store, retrieve, manipulate, transmit or receive information electronically. It was posited that construction work generate a lot of data and information which must be exchanged and communicated (MASQOOD et al., 2004). This is made easy through the adoption of ICT.

However, Mohamed and Stewart (2003) observed that majority of construction process information exchange have been through the traditional means of communication, such as faceto-face meetings and the exchange of paper documents in the form of technical drawings, specifications and site instructions. This situation accounts for difficulty in accessing data, and the prevalence of out-of-date and incomplete information within the construction industry (SHOESMITH, 1995). Thus, there is the need to increase the efficiency of information management by exchanging massive volumes of information at high speed and at relatively low cost through the deployment of ICT in the industry (DENG et al., 2001).

Oyetunji et al. (2018) investigated the factors influencing the deployment of ICT in Nigerian real estate practices in Lagos states, and found that technological infrastructure, service delivery efficiency enhancement, and productivity branding are the factors that influenced the ICT deployment. The study adopted questionnaire as its tool and factor analytical test as the tool for analysis.

Mutesi and Kyakula (2011) assessed the application of ICT in the Ugandan construction industry, the study was aimed at determining the level of ICT penetration, impact and constraints within companies in Kampala. It was found that the most commonly used software are; Microsoft word, MS excel, PowerPoint, AutoCAD, master bill and Microsoft project. The benefits of using ICT are increased productivity, time savings, reduced risks and mistakes, and simplified complex tasks. The major constraints in the use of ICT high investment cost, virus attached/ malfunction of systems, and high cost of engaging expertise.

Peansupap and Walker (2006) investigated innovation diffusion at the implementation construction phase of a project, with emphasis on information communication technology. The study reported that ICT application planning requires the consideration of variables such as management and technical support, favourable working environment, and the characteristics 
DOI: 10.14807/ijmp.v11i4.1096

of the individual users of ICT; for effective framework development. Ibironke et al. (2011) reported that a high initial cost of acquisition, lack of infrastructure to support its use and security concerns such as the susceptibility of ICT system are some of the major factors influencing the use of this system.

Gagnon et al. (2012) reviewed the factors influencing the adoption of information and communication technologies by health experts, and reported that time, knowledge of ICT, ease of use, system usefulness, and design and technical issues were the factors influencing ICT adoption. Ugwuanyi and Ugwu (2015) assessed the impact of Information and Communication Technology (ICT) Application in Nigerian Construction Industry, and reported that the cost of ICT infrastructure and power supply, cost of training of IT staff, capital outlay with no guarantee of likely returns were the major hindrances to ICT adoption and implementation in construction

Afolabi et al. (2019) examined the critical Success Factors (CSFs) for e-Procurement adoption in the Nigerian Construction Industry, and found that availability of reliable, affordable and fast Internet services, reliable ICT infrastructure, availability of trained personnel and constant power supply; are the most critical success factor for e-Procurement technologies adoption. The study concluded that management support for physical infrastructure, human factors, and characteristics of the technology; were the crucial factors required for the adoption of e-Procurement systems in the Nigerian construction industry.

Eze et al. (2019) assessed the factors limiting the full-scale adoption of process and product innovation by construction organizations in Nigeria and found that poor funding, poor support and commitment from management, fragmented nature of the construction business, poor coordination and communication among project participants, lack of qualified and experienced staff were the major factors limiting innovations in construction.

ICT and innovation based studies exist in construction especially in some countries with developed construction economies. These include studies carried out in Denmark (SAMUELSON, 2002), Canada (RIVARD, 2000), Malaysia (LIM et al., 2002), South Africa (ARIF; KARAM, 2001), Singapore 2003, (GOH, 2005), and in Turkey (SARSHAR; ISIKDAG, 2004). However, little is has been done on aspect of factors influencing ICT adoption and implementation in construction.

Similarly, there exist studies that significant literature abounds in the aspect of ICT in the Nigerian construction industry. However, not much has been done in assessing the factors 
DOI: 10.14807/ijmp.v11i4.1096

influencing innovative ICT facilities deployment among construction firms in the study area. With the understanding of the significant impact of socio-economic and physical environment on the quality of services delivered by construction organisations through their professional employees (KAZAZ; ULUBEYLI, 2009), there is, therefore, the need to assess the factors influencing the deployment of innovative ICT tools in Port Harcourt.

This study is therefore, aimed at assessing the factors influencing the deployment of innovative ICT facilities among construction firms, taking the perspective of constructionbased professional employees. The working objective of the study is to determine the factors influencing the deployment of ICT in construction, and to recommend possible measure for increasing ICT deployment in construction work in Port Harcourt.

It is the understanding of this study that the findings will propel and catalyze a rapid and a more comprehensive consideration and exploitation of technology by construction firms' for used in construction projects. This has become necessary so that firms will take the advantages inherent in the use of ICT. In addition, decision makers in the industry will be spurred into actions that will entrench the application of ICT facilities in all construction processes and practices.

\section{REVIEW OF LITERATURE}

\subsection{ICT Development in the Construction Industry}

There is an increasing trend in the way construction organisations are responding to ICT facilities application in construction transactions. For several years, there have been sporadic evolution in the deployment and developments of ICT such as email, internet, video conferencing, e-tendering, e-procurement, software, etc. in the construction sectors of both developed and developing economies (UK ESSAY, 2018).

Early twenties researchers have linked these changes to the level of competition and globalisation, innovative strategies being adopted by big firms, clients demands and sophistication, changing industry advancement in information and communication technology. Critical among these changes is the shift in companies traditional paper-based approach to the use of computer based techniques in the running of day-to-day activities of the firms (ALABI; ANIFOWOSE, 2018). Simialarly, HALIM (2010) pointed out that, the advent of innovation technologies have enhanced the operations of construction organisations globally

Similarly, Peansupap and Walker (2005) posits that evolving ICT have presented prospects for refining and making communication within the construction industry to be more 
DOI: 10.14807/ijmp.v11i4.1096

effective at every facets of a the construction projects, and in creating new market for businesses. It was further stressed that ICT related expenditure now forms a larger chunk of the overall construction firms annual running cost. Although, ICT deployment is still relative low in the construction industry (WOKSEPP; OLOFSSON, 2006).

However, the awareness of ICT utilisation is high, its cost of deployment and upgrade of the system have limited the usage, especially for smaller firms. The integration of different ICT facilities within the industry and among the construction professionals is important. This is necessary for standardisation of processes and to reap full benefits of ICT adoption (UK ESSAY, 2018).

In the UK, construction firms see benefits in implementing and using new technologies, which will assist in the attainment of strong competitive advantage. This importance is, however, most times ignored due to their unwillingness to invest in new innovative technologies. Returns on investment has always hindered and prevented most decisions to invest on ICT. In Turkey, Sarshar and Isikdag (2004) opined that there is inefficient communication and loss of information due to fragmentation in the industry. Even though, the deployment level of ICT in construction is still at the infancy.

\subsection{Information Communication and Technology (ICT) Deployment Tools}

The essential tools for ICT deployment are hardware and softwares. While the hardware comprises majorly of the different types of computerised gadgets, the softwares ranges from word processing softwares to design softwares. The common types of software used in construction include: Word processing; Spreadsheet; CAD (Revit, AutoCAD, ArchiCAD); Internet software; BIM (Building Information Model); RFID (Radio Frequency Identification); Super Project, Master Bill, WinQs, QSlotus, Computer Aided Taking Off (CATO), Digitizers, Estimator Pro.MB 3, QS Cad, RIPAC, EVEREST, Kwikest, Microsoft Navision; Project extranet; Microsoft project etc. These softwares are used for administration, marketing, desktop publishing, presentation and project management (ARIF; KARAM, 2001).

While architects, engineers and contractors use CAD mostly for design, drawing and presentation, quantity surveyors use it for measurement, preparation of bills of quantities (BOQ), estimating, and presentation. Production difficulties in the construction industry has strong relation to the communication and information exchange between the parties involved in the construction project (UK ESSAY, 2018). 
DOI: 10.14807/ijmp.v11i4.1096

Oladapo (2007) pointed out that the basic modes of acquisition of computer literacy available to construction professionals are through private lessons, self-taught, in service training given by employer, and continuous professional development training by professional bodies were the major modes, and lastly learning at school. The use of self-taught is most common and this is a reflection of the very low ICT contents of construction education in Nigeria.

\subsection{Factors Influencing ICT deployment in the construction industry}

The large number of stakeholders involved in any construction projects requires that a large volume of information exchange is needed to keep every party updated. The number of skilled professional and companies whose activities are repetitive and with the large volume of traditional paperwork, regular access to project information is required almost on daily basis (MURRAY et al., 2001).

Therefore, for the overall success of construction project, all the participants require effective and efficient information exchange. This is so as construction drawings, bills of quantities, schedules, programmes, specifications are still being exchanged manually and requires physical and direct face-to-face communication amongst practitioners in the industry (HORE; WEST, 2005).

In an attempt to assessing the barriers hindering the promotion of use of ICT in the construction industry of Ghana, Sekou (2012) reported that the most important factors limiting their usage include; budget constraints for ICT investments, lack of support and commitment on ICT by top management of firms, lack of training and technical support for professionals in ICT, inadequate ICT content of construction education, and lack of interest on ICT based firms by majority of construction clients. Earlier, Laryea (2010) confirmed that high cost of capital and funding issues have remained the major factors limiting contractors from investing in ICT facilities and their deployment in construction processes.

Alaghbandrad et al. (2012) investigated the problems and barriers of ICT utilization on Iranian construction sites. It was reported that the major limiting factors to it utilization are poor ICT infrastructure, lack of local personnel familiar with ICT systems in remote construction sites, no economic justification for ICT training of personnel in small construction sites, inapplicable software outputs, complicated administrative process for ICT development, and poor back up system in remote construction sites. In real estate industry, Oyetunji et al. (2018) assessed the factors that Influence the deployment of ICT in real estate practice and 
DOI: 10.14807/ijmp.v11i4.1096

found that technological infrastructure, service delivery efficiency enhancement, and productivity branding influenced the deployment of ICTs in real estate industry.

Poor/insufficient power supply, inadequate ICT content in construction, scarcity of professional software, high cost of engaging computer staff, lack of management desire and appreciation of ICT, security issues, low return on investment in ICT, high cost of hardware/software, fear of virus attack, high rate of obsolescence of software/hardware, personnel abuse, and fear of ICT making professionals redundant, were identified by (OLADAPO, 2007) as the major constraint to the acceptance of ICT facilities.

Rate of virus attack leading to loss of data, rate of software becoming outdated and updating, durability of locally assembled computers, replace-ability issues of branded computers, institutions of higher learning not equipped enough for computer education, lack of encouragement to invest in computers, cost of hiring computer experts, lack of management support to ICT; were among the factors responsible for the slow pace of acceptance of ICT among construction professionals like the quantity surveyors (OYEDIRAN; ODUSAMI, 2005; IBIRONKE et al., 2011).

In addition, Waziri et al. (2017) revealed that construction organizations are reluctant to adopt new technologies due to unfavourable economic environment. Furthermore, REZGUI et al. (2004) asserted that the reasons for the relatively low adoption of ICT are issues relating to the legal ramifications of electronic communications, vague security framework, and issue of trust. Also, organizational and human issues were highlighted as the key factors affecting the use of technologies in the construction sector (OYEDIRAN; AKINTOLA, 2011). Table 1 shows the summary of some selected factors influencing ICT deployment in construction.

Table 1: Factors Influencing ICT Deployment in Construction

\begin{tabular}{|c|c|c|}
\hline S/No. & Factors & Sources \\
\hline 1 & Changes in technologies & $\begin{array}{l}\text { MUTESI; KYAKULA (2011); OLADAPO (2007); } \\
\text { OYETUNJI et al. (2018); ALABI ; ANIFOWOSE } \\
\text { (2018) }\end{array}$ \\
\hline 2 & Cost of computer hardware and software & $\begin{array}{l}\text { MUTESI; KYAKULA (2011); OLADAPO(2007); } \\
\text { OYETUNJI et al. (2018); ALABI ; ANIFOWOSE } \\
\text { (2018) }\end{array}$ \\
\hline 3 & Insufficient and/or Erratic power supply & $\begin{array}{l}\text { MUTESI; KYAKULA (2011); OLADAPO (2007); } \\
\text { ALABI; ANIFOWOSE (2018) }\end{array}$ \\
\hline 4 & $\begin{array}{l}\text { Response /Attitude of top management innovative } \\
\text { technologies }\end{array}$ & MUTESI; KYAKULA (2011); OLADAPO (2007) \\
\hline 5 & Inadequate financial resources & $\begin{array}{l}\text { MUTESI; KYAKULA (2011); ALABI ; } \\
\text { ANIFOWOSE (2018) }\end{array}$ \\
\hline 6 & Need to be ahead of competitors & OLADAPO(2007); OYETUNJi et al. (2018) \\
\hline 7 & Inadequate trained ICT professionals & $\begin{array}{l}\text { MUTESI; KYAKULA (2011); ALABI ; } \\
\text { ANIFOWOSE (2018) }\end{array}$ \\
\hline
\end{tabular}


DOI: 10.14807/ijmp.v11i4.1096

Satisfaction with existing method of working

Virus attack, security breach and fear of accuracy

Fear of job losses /making professionals redundant

Need to improve productivity

Size and age of firm/organisation

ownership of firm (Foresign and /or indegenous)

To eliminate distance barriers and improve information sharing

to reduce the cost of personnel

Lack of information by professionals on areas of adoption

Lack of legal support for use of ICT

High cost of training ICT professionals

Inadequate knowledge about return on ICT investment

Security concerns/privacy fears

Inability to quantify process improvements and uncertainty of benefits of ICT

Demand by Customer/client

ICT infrastructure issues
ALABI; ANIFOWOSE (2018)

MUTESI; KYAKULA (2011); ALABI ;

ANIFOWOSE (2018)

MUTESI; KYAKULA (2011); ALABI;

ANIFOWOSE (2018)

OLADAPO (2007); OYETUNJI et al. (2018)

OLADAPO (2007); OYETUNJI et al. (2018)

OLADAPO (2007)

OYETUNJI et al. (2018).

OYETUNJI et al. (2018).

ALABI ; ANIFOWOSE (2018)

ALABI ; ANIFOWOSE (2018)

ALABI ; ANIFOWOSE (2018)

MUTESI ; KYAKULA (2011); ALABI ; ANIFOWOSE (2018)

ALABI; ANIFOWOSE (2018)

ALABI ; ANIFOWOSE (2018)

OLADAPO (2007)

AFOLABI et al. (2019), ALAGHBANDRAD et al. (2012), OYETUNJI et al. (2018), IBIRONKE et al. (2011)

\section{RESEARCH METHODOLOGY}

This study covered the assessment of the factors influencing innovative ICT facilities deployment in construction organisations in Port Harcourt. The choice of selecting Port Harcourt for the study is based on the premise that Port Harcourt is located in rivers state, which is one of the oil-rich States of Nigeria. These attract a lot of professionals, investors and developers to Port Harcourt. The government of the day is implementing many construction and developmental projects around the city of Port Harcourt. Thus, the in-flux of various construction professionals to Port Harcourt.

The study adopted a well-structured questionnaire administered personally by the researchers to the professionals. Questionnaire is one of the most used techniques for conducting social research. It involves the formulation of precise written questions for the respondents, whose opinion is being sort (BLAXTER et al., 2001).

The questionnaire used for this study has two sections. Section A of the questionnaire was used to gather data on the respondents' background. The information collected in this section will serve a quality check to the data obtained from the other section of the questionnaire. Section B assessed the factors influencing the deployment of innovative ICT 
DOI: 10.14807/ijmp.v11i4.1096

facilities in construction organisation. The design of the research instrument was facilitated by information derived from related literatures reviewed

Population is a collection of elements being studied and about which conclusions are to be drawn (KOTHARI, 2004). The population for this study are professionals in constructionbased organisation (i.e. civil and heavy engineering contractors, building contractors and housing developers) in the study area. These professionals include Civil \& services engineers, professional builders, Architects, Quantity Surveyors, estate surveyors and valuers.

A total of 372 questionnaires were administered within the period of the study, using simple random sampling techniques. The respondents were given considerable amount of time to reflect and enable giving of valid responses to the items contained in the research instrument. 260 questionnaires were retrieved, 6 were discarded as a result of incomplete response. 254 were deem fit and used for the analysis. This represent an effective response rate of $68.28 \%$, and this is far above the usual response rate of 20-30\% for questionnaire surveys in construction management studies, as suggested by (AKINTOYE, 2000).

The study employed Percentile and Factor Analysis (Principal component analysis, PCA and varimax rotation for factor extraction) in the data analysis. The background information of the respondents was analysed using Percentile. Factor analysis was adopted in order to reduce the factors into a manageable number and suitably group them and in ranking the key factors.

Eze et al. (2018) posits that factors analysis is suitable for analysing and grouping variable in to more significant and manageable portion. Field (2005) posits that PCA is concerned mostly with establishing which linear components exist within the data and how a particular variable might contribute to that component.

According to Eze et al. (2018), the principal component analysis (PCA) is one of the techniques of factor analysis used for determining whether there exist a relationship amongst the variables or not (i.e. factor extraction). PCA technique is suitable for factor extraction because it is psychometrically sound and mathematically simpler (PALLANT, 2007). These analyses were performed using statistical package for social science (SPSS 20, IBM).

Prior to the final draft of the questionnaire, a pilot survey was adopted to test the suitability and appropriateness of the questionnaire to meet the study objectives. Fellows and Liu (2008) suggested a pilot study for suitability of research instrument to meeting study aim. 
DOI: 10.14807/ijmp.v11i4.1096

12 of the initial draft questionnaire were randomly distributed to the selected experts and based on the feedback, the final draft was made.

Furthermore, to ascertain the accuracy of the results that would be obtained from the research instrument, a reliability test was done using Cronbach's alpha test $(\alpha)$ as suggested by (KOTHARI, 2004). This test was used to measure the reliability and internal consistency of the extracted data from the research instrument.

Pallant (2005) posits that the Cronbach alpha coefficient of a scale should be above 0.7. The closer the alpha $(\alpha)$ is to 1 , the greater the internal consistency of items in the instrument. The Cronbach alpha value for the variables as extracted from the questionaire is 0.880 (see Table 2). With this value, the questionnaire was adjudged credible, reliable and have high internal consistency as confirmed by (PALLANT, 2005).

Table 2: Reliability statistics

\begin{tabular}{llcccc}
\hline \multicolumn{5}{c}{ Case Processing Summary } \\
\hline \multirow{3}{*}{ Case 1} & $\mathrm{~N}$ & $\%$ & & \\
& & & & & \\
& Valid $^{*}$ & 254 & 100 & Cronbach's Alpha & 0.880 \\
& Excluded $^{\mathrm{a}}$ & 0 & 0 & N of Items & 23 \\
\hline
\end{tabular}

a. Listwise deletion based on all variables in the procedure.

Case 1- factors influencing ICT deployment

\section{RESULTS AND DISCUSSION}

The analysis of the data gathered on the general information of the respondents show that, on the basis of their organisational type (33.07\%) work with building construction firms, (50.39\%) work with Civil/heavy Engineering firms, and the remaining (16.54\%) work with Consultant organisations. With regards to their year of experience, $(6.30 \%)$ of them have experience between 1 - 5 years, (28.74\%) have worked between 6 - 10 years, (31.10\%) have worked between 11 - 15 years, (18.90\%) of them have worked for between 16 - 20 and finally (14.96\%) of them have worked for 21years and above.

The average number of years of experience of the respondents was put at 11.5 years. In a nutshell, it was inferred that these respondents have spent a good length of time in their present organisations and have the requite experiences to give a reasonable and reliable insight to the happenings within their organisations.

Furthermore, majority of the respondents are Engineers (36.22\%) and this is followed by the Quantity surveyors (30.71\%), Architects (12.6\%), Builders (10.63\%), and lastly, Estate valuers (9.84\%). For academic qualification is (44.88\%) of them have Masters of Science/Technology, (30.31\%) have Bachelor of Science/Technology, (22.44\%) have Higher 
DOI: 10.14807/ijmp.v11i4.1096

National Diploma and those with Doctorate degree are (2.36\%). This result suggest that the respondents are academically equipment to make an informed contribution to the subject of this study.

Their professionally qualification shows that (83.86\%) of them are corporate members of their various professional bodies, (11.02\%) are probationer members and finally (5.12\%) are fellow members. Surprisingly, $82.28 \%$ of the respondents indicated that their firms engage the services of ICT specialist and $17.72 \%$ of them indicated that their firms do not engage the services of ICT specialist. This implies that only $17.72 \%$ rely on the services of external/contract ICT specialist based on needs. Since, a larger number of the firms engage the services of an in-house ICT specialist; it means innovative ICT technologies have been embraced by construction firms in the area of the study.

The findings from the background information of the respondents indicate that responses gathered from them can be relied upon in making valid and generalised conclusion on the subject under consideration.

Table 3: Demographic characteristics of Respondents

\begin{tabular}{|c|c|c|c|c|}
\hline Category & Classification & Freq. & $\%$ & $\begin{array}{c}\text { Cum. } \\
\%\end{array}$ \\
\hline \multirow[t]{4}{*}{ Organisational Type } & Building construction & 84 & 33.07 & 33.07 \\
\hline & Civil/ heavy engineering firm & 128 & 50.39 & 83.46 \\
\hline & consultancy firm & 42 & 16.54 & 100.00 \\
\hline & TOTAL & 254 & 100.00 & \\
\hline \multirow[t]{6}{*}{ Years of experience } & 1-5years & 16 & 6.30 & 6.30 \\
\hline & $6-10$ years & 73 & 28.74 & 35.04 \\
\hline & $11-15$ years & 79 & 31.10 & 66.14 \\
\hline & 16-20 years & 48 & 18.90 & 85.04 \\
\hline & 21-above & 38 & 14.96 & 100.00 \\
\hline & TOTAL & 254 & 100.00 & \\
\hline \multirow[t]{6}{*}{ Professions of Respondents } & Architects & 32 & 12.60 & 12.60 \\
\hline & Builders & 27 & 10.63 & 23.23 \\
\hline & Engineers & 92 & 36.22 & 59.45 \\
\hline & Estate Surveyors \& valuers & 25 & 9.84 & 69.29 \\
\hline & Quantity Surveyors & 78 & 30.71 & 100.00 \\
\hline & TOTAL & 254 & 100.00 & \\
\hline \multirow[t]{5}{*}{ Academic Qualification } & Higher National Diploma & 57 & 22.44 & 22.44 \\
\hline & Bsc/Btech & 77 & 30.31 & 52.76 \\
\hline & Master degree & 114 & 44.88 & 97.64 \\
\hline & Doctorate degree & 6 & 2.36 & 100.00 \\
\hline & TOTAL & 254 & 100.00 & \\
\hline Professional Qualification & Fellow members & 13 & 5.12 & 5.12 \\
\hline
\end{tabular}


DOI: 10.14807/ijmp.v11i4.1096

\begin{tabular}{llccc} 
& Corporate member & 213 & 83.86 & 88.98 \\
& Probationer members & 28 & 11.02 & 100.00 \\
& TOTAL & $\mathbf{2 5 4}$ & $\mathbf{1 0 0 . 0 0}$ & \\
$\begin{array}{l}\text { Firms Engagement of ICT } \\
\text { expert/specialist }\end{array}$ & Yes & 209 & 82.28 & 82.28 \\
& No & 45 & 17.72 & 100.00 \\
& TOTAL & $\mathbf{2 5 4}$ & $\mathbf{1 0 0 . 0 0}$ & \\
\hline
\end{tabular}

4.1. Factor Analysis of the factors influencing the Deployment of innovative ICT facilities in construction

In order to group the 23 identified factors from literature into a more significant and manageable proportion, factor analysis was employed. It was deemed fit to scale down these factors into a smaller number of logical size. In doing this, the suitability of the data gathered for factor analysis was first determined by putting in consideration the number of variables and sample size involved. It was opinion by Pallant (2005) that a larger sample should be used for factor analysis, this position was taken after it was observed that little agreement exist among researchers regarding the sample size for factors analysis.

It was further suggested by Tabachnick and Fidell (2007) that the sample size for factor analysis should be from 150 to 300. According to Mundfrom et al. (2005), the minimum sample size should be from 3 to 20 times the number of variables where factor analysis technique is being considered, and confirmed that an absolute range of 100 to more than 1000 is ideal.

Although. Studies exist on factor analysis where smaller sample size was considered. For example, in Uk and Akintoye (2000) conducted factor analysis for a sample size of eightyfour (84). Also, in Malaysia, Takim and Adnan (2008) analysed the effectiveness of the measures of construction project success using factor analysis among ninety-three (93) respondents. Therefore, the sample size of 254 adopted in this study can arguably be said to be adequate and suitable for factor analysis.

Concerning the number of variables, it was suggested by Hair et al. (1998) that 20-50 variables are suitable for factor analysis. It was held that if this number range is exceeded, the extraction of common factors becomes inaccurate. However, when the sample size is large, less number of variables can be used. This has been shown by studies according to (AHADZIE et al., 2008). Hence, the 23 factors coupled with the sample size of 254 were considered satisfactory for factor analysis. 
DOI: 10.14807/ijmp.v11i4.1096

Another way of establishing the factorability and suitability of the data gathered for factor analysis was to determine the existence of a patterned relationship amongst the variables using Kaiser-Meyer-Olkin (KMO) measure of sampling adequacy and Bartlett's test of sphericity. Eze et al. (2018) posits that the variables are said to have achieved a patterned relationship when the significant level of $\mathrm{p}($ sig.) is less than 0.50 .

According to (YONG; PEARCE 2013), the cut-off for adequacy of the variables is when the KMO measure of sampling adequacy is 0.50 and above. KMO is a measure of homogeneity of variables and it now commonly used in testing the magnitude of the partial correlation which exist among variables (SHARMA, 1996). For a good factor analysis, a minimum value of KMO should be 0.60 , though, KMO index ranges from $0-1$ (TABACHNICK; FIDELL, 2007).

In the opinion of Hair et al. (1998) and Stern (2010), a KMO value greater than 0.7 is suitable for factor analysis if the sample size is adequate. This implies that a KMO value between 0.5 and 0.7 is adequate, while lower than 0.5 is considered to be unsuitable for factor analysis.

Bartlett's test of sphericity indicates whether the correlation matrix is an identity matrix (PALLANT, 2005). For factor analysis to be considered appropriate, it was advocated that a Bartlett's test of sphericity with p-value (or sig.) of less than 0.05 as ideal. Result in Table 4 shows that the use of factor analysis for the data gathered was appropriate. This is evident from the KMO value of 0.835 and a significant level of 0.000 for the Bartletts test, and coupled with the 0.880 result obtained from the reliability test carried out through the use Cronbach's alpha test.

Table 4: KMO and Bartlett's Test

\begin{tabular}{lccc}
\hline & Bartlett's Test of Sphericity & & \\
\cline { 2 - 2 } Approx. Chi-Square & 5165.722 & KMO and Bartlett's Test & 0.835 \\
df & 253 & & \\
Sig. & 0.000 & \\
\hline
\end{tabular}

Source: Researchers’ analysis, 2019

Having established the suitability of the data for factor analysis, factor analysis was conducted using principal component analysis (PCA) with varimax rotation as the extraction method. Result in Table 5 shows that 4 components with eigenvalues greater than 1 were extracted using the factor loading of 0.50 as the cut-off point as suggested by (SPECTOR, 1992). 
DOI: 10.14807/ijmp.v11i4.1096

The total variance explained by each component extracted is as follows; component 1 with $29.77 \%$, component 2 with 24.82\%, component 3 with $8.84 \%$, and component 4 with 4.96\%. The final statistics of the PCA and the components extracted accounted for approximately $68.38 \%$ of the total cumulative variance. Thus, COSTELLO; JASON (2005); PALLANT (2007); STERN (2010) criterion of factors explaining at least 50\% of the variation is fulfilled.

Table 5: Total Variance Explained

\begin{tabular}{|c|c|c|c|c|c|c|c|c|c|}
\hline \multirow{2}{*}{ Component } & \multicolumn{3}{|c|}{ Initial Eigenvalues } & \multicolumn{3}{|c|}{$\begin{array}{c}\text { Extraction Sums of Squared } \\
\text { Loadings }\end{array}$} & \multicolumn{3}{|c|}{$\begin{array}{c}\text { Rotation Sums of Squared } \\
\text { Loadings }\end{array}$} \\
\hline & Total & $\begin{array}{c}\text { \% of } \\
\text { Variance }\end{array}$ & $\begin{array}{c}\text { Cumulative } \\
\%\end{array}$ & Total & $\begin{array}{c}\% \text { of } \\
\text { Variance }\end{array}$ & $\begin{array}{c}\text { Cumulative } \\
\%\end{array}$ & Total & $\begin{array}{c}\text { \% of } \\
\text { Variance }\end{array}$ & $\begin{array}{c}\text { Cumulative } \\
\%\end{array}$ \\
\hline 1 & 6.847 & 29.77 & 29.77 & 6.847 & 29.77 & 29.77 & 4.759 & 20.692 & 20.692 \\
\hline 2 & 5.709 & 24.822 & 54.591 & 5.709 & 24.822 & 54.591 & 4.283 & 18.624 & 39.316 \\
\hline 3 & 2.032 & 8.84 & 63.428 & 2.032 & 8.84 & 63.428 & 3.35 & 14.564 & 53.88 \\
\hline 4 & 1.138 & 4.95 & 68.378 & 1.138 & 4.95 & 68.378 & 3.334 & 14.498 & 68.378 \\
\hline 5 & 0.904 & 3.93 & 72.308 & & & & & & \\
\hline 6 & 0.854 & 3.712 & 76.02 & & & & & & \\
\hline 7 & 0.782 & 3.399 & 79.419 & & & & & & \\
\hline 8 & 0.682 & 2.966 & 82.385 & & & & & & \\
\hline 9 & 0.6 & 2.611 & 84.995 & & & & & & \\
\hline 10 & 0.528 & 2.298 & 87.293 & & & & & & \\
\hline 11 & 0.462 & 2.01 & 89.303 & & & & & & \\
\hline 12 & 0.412 & 1.792 & 91.095 & & & & & & \\
\hline 13 & 0.388 & 1.687 & 92.782 & & & & & & \\
\hline 14 & 0.363 & 1.579 & 94.361 & & & & & & \\
\hline 15 & 0.309 & 1.345 & 95.706 & & & & & & \\
\hline 16 & 0.263 & 1.143 & 96.849 & & & & & & \\
\hline 17 & 0.214 & 0.93 & 97.779 & & & & & & \\
\hline 18 & 0.161 & 0.701 & 98.48 & & & & & & \\
\hline 19 & 0.114 & 0.496 & 98.975 & & & & & & \\
\hline 20 & 0.11 & 0.478 & 99.453 & & & & & & \\
\hline 21 & 0.059 & 0.255 & 99.708 & & & & & & \\
\hline 22 & 0.044 & 0.19 & 99.899 & & & & & & \\
\hline 23 & 0.023 & 0.101 & 100 & & & & & & \\
\hline
\end{tabular}

Source: Researchers’ analysis, 2019

Another technique of determining the number of factors (component) to extract or retain, is by examining the scree plot as suggested by Pallant (2005). It was suggested that a critical look at the scree plot is necessary in other to determine which components (factors) to extract or retain. In analysing the scree plot, a change in the shape of the plot is identified and only components above this point are retained, and the point at which the break occurred should not be included (COSTELLO; JASON, 2005).

A look at the figure 1 shows that the plot tend to flatten from the fifth component; therefore, only components from this point above are retained. This further confirms the result in Table 5 which shows only 4 components with eigenvalues greater than 1 . 
INDEPENDENT JOURNAL OF MANAGEMENT \& PRODUCTION (IJM\&P)

http://www.ijmp.jor.br

v. 11, n. 4, July - August 2020

ISSN: 2236-269X

DOI: 10.14807/ijmp.v11i4.1096

The result in Table 6 summarizes the factor loading on each of the four extracted and their variables. According to SPECTOR (1992), a clear component structure is present when a variable has significant factor loading (loading $>0.50$ ) on one component only. Hence only elements with 0.5 and above are considered under each component.

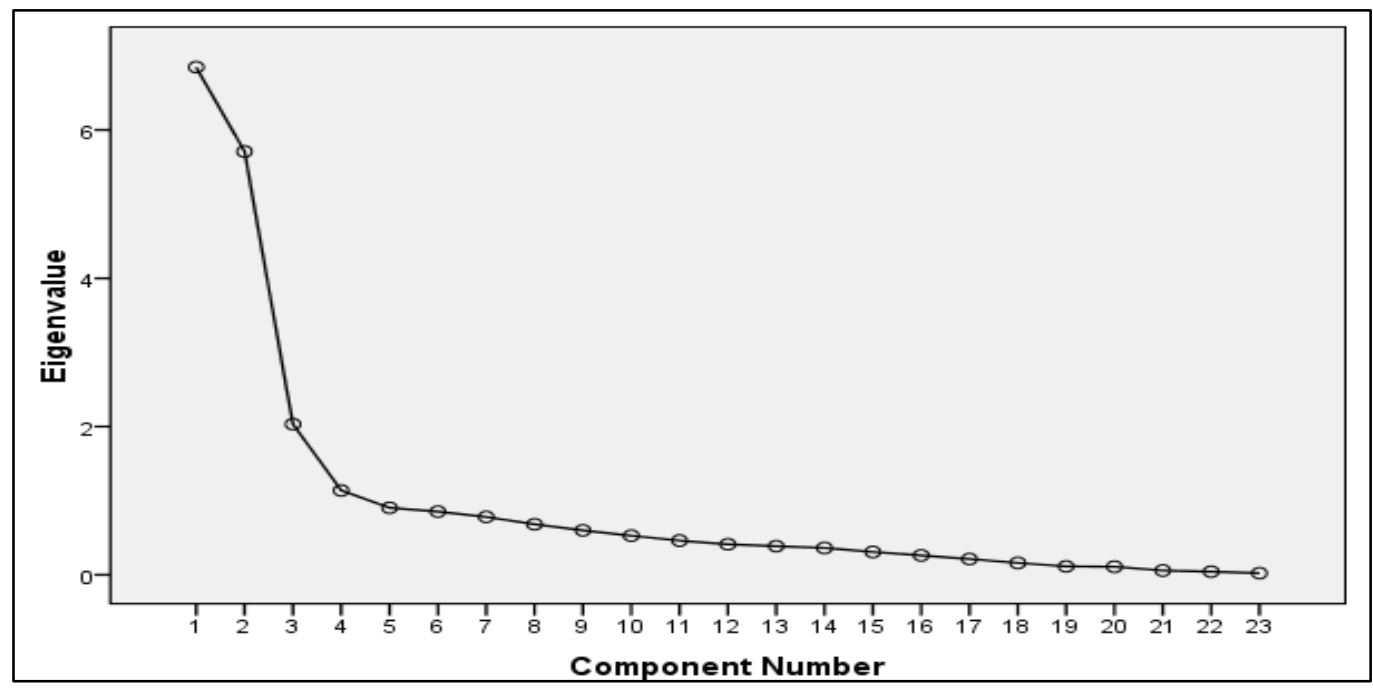

Figure 1: Scree Plot

Table 6: Rotated components matrix

\begin{tabular}{|c|c|c|c|c|c|c|}
\hline & & Comp & onent & & & Don \\
\hline & 1 & 2 & 3 & 4 & loading & Kank \\
\hline Satisfaction with existing method of working & 0.944 & & & & 0.944 & 1 st \\
\hline Inadequate trained ICT professionals & 0.940 & & & & 0.940 & 2nd \\
\hline Inadequate financial resources & 0.889 & & & & 0.889 & 6th \\
\hline Lack of information by professionals on areas of adoption & 0.697 & & & & 0.697 & 12th \\
\hline Need to be ahead of competitors & 0.655 & & & & 0.655 & 14th \\
\hline ICT infrastructure issues & 0.635 & & & & 0.635 & 17th \\
\hline $\begin{array}{l}\text { Inability to quantify process improvements and uncertainty of } \\
\text { benefits of ICT }\end{array}$ & 0.618 & & & & 0.618 & 18th \\
\hline Inadequate knowledge about return on ICT investment & & 0.929 & & & 0.929 & 3rd \\
\hline Virus attack, security breach and fear of accuracy & & 0.928 & & & 0.928 & 4th \\
\hline Lack of legal support for use of ICT & & 0.911 & & & 0.911 & 5th \\
\hline Security concerns/privacy fears & & 0.881 & & & 0.881 & 7th \\
\hline Changes in technologies & & & & & 0.000 & 22nd \\
\hline Fear of job losses /making professionals redundant & & & 0.734 & & 0.734 & 10th \\
\hline High cost of training ICT professionals & & & 0.704 & & 0.704 & 11th \\
\hline Demand by Customer/client & & & 0.653 & & 0.653 & 15 th \\
\hline Need to improve productivity & & & 0.637 & & 0.637 & 16th \\
\hline Response /Attitude of top management innovative technologies & & & 0.618 & & 0.618 & 18th \\
\hline Insufficient and/or Erratic power supply & & & 0.531 & & 0.531 & 21st \\
\hline To reduce the cost of personnel & & & & 0.834 & 0.834 & 8th \\
\hline Cost of computer hardware and software & & & & 0.798 & 0.798 & 9th \\
\hline Size and age of firm/organisation & & & & 0.671 & 0.671 & 13th \\
\hline To eliminate distance barriers and improve information sharing & & & & 0.599 & 0.599 & 20th \\
\hline ownership of firm (Foreign and /or indigenous) & & & & & 0.000 & 22nd \\
\hline
\end{tabular}


DOI: 10.14807/ijmp.v11i4.1096

Source: Researchers’ analysis, 2019

\subsection{Discussion of The Extracted Factors}

A. Change related issues: The first principal component had the highest factor loading of seven variables, thus, accounted for about $30 \%$ of the total variance explained. These variables include; satisfaction with existing method of working, inadequate trained ICT professionals, Inadequate financial resources, lack of information by professionals on areas of adoption, need to be ahead of competitors, and ICT infrastructure issues. After a critical examination of the latent characteristics of these factors, it was observed that they were related to refusal to change and insistence on the traditional method of operation. Thus, the component was named “change related issues”.

B. Security related concerns: The second principal component had factor loading of four variables, thus, accounted for about $25 \%$ of the total variance explained. The factors loading on this component are; inadequate knowledge about return on ICT investment, virus attack, security breach and fear of accuracy, lack of legal support for use of ICT, and security concerns/privacy fears. A critical examination of these variables showed they are related to security of investment, fear of internet fraud, legal and privacy issues. Based on these, this component was subsequently name "security related concerns”.

C. Human and management related Concerns: The third principal component had factor loading of six variables, thus, accounting for about $9 \%$ of the total variance explained. These six factors loaded on this component include; fear of job losses /making professionals redundant, high cost of training ICT professionals, demand by Customer/client, need to improve productivity, response /Attitude of top management innovative technologies, and insufficient and/or erratic power supply. Examination of the latent characteristics of these variables shows they are related to individual and organisational issues within the construction industry. It is based on this that the component was named "human and management related concerns”.

D. Cost related Concerns: The fourth principal component had factor loading of four variables, thus, accounting for about $5 \%$ of the total variance explained. These four factors are; to reduce the cost of personnel, cost of computer hardware and software, size and age of firm/organisation, and to eliminate distance barriers and improve information sharing. After a critical examination of the latent characteristics of these factors, it was observed 
DOI: 10.14807/ijmp.v11i4.1096

that they are related to concerns for cost in organisations. Based on this, the component was subsequently named “cost related concerns”.

These factors were further ranked using the factor loading as shown in column 6 and 7 of Table 6. Based on the factor loading, the top five (5) ranked factor is satisfaction with existing method of working (94.4\%), next is inadequate trained ICT professionals (94.0\%), inadequate knowledge about return on ICT investment, Virus attack, security breach and fear of accuracy, and lack of legal support for use of ICT with a factor loading of 92.9\%, 92.8\% and $91.1 \%$ respectively.

Changes in technologies and ownership of firm (Foreign and /or indigenous) with $0.00 \%$ factor loading were the least. This, however, calls for further reflection on these two factors. Overall, the average factor loading for this factors is 0.6872 (68.72\%) and this is quite above 0.50 loading. These factors can be said to exert a considerable influence on the deployment of ICT in construction processes.

The findings of this study regarding the factor influencing the deployment of innovative ICT facilities in construction practices are in line with Laryea (2010), Sekou (2012), Alaghbandrad et al. (2012) and Oyetunji et al. (2018). According to Laryea (2010), the high cost of capital and funding issues have remained a major concern for contractors in considering investment in ICT facilities and their deployment in construction processes.

Similarly, Sekou (2012) found that budget constraints, lack of top management support, lack of training and technical support for professionals in ICT, inadequate ICT content of construction education, and lack of interest by majority of construction clients on ICT; were major issues in considering the adoption of ICT in construction.

Alaghbandrad et al. (2012) found that the major limiting factors to IT utilization are poor ICT infrastructure, lack of local personnel familiar with ICT systems in remote construction sites, and no economic justification for ICT training of personnel in small construction sites. Oyetunji et al. (2018) also reported that technological infrastructure, service delivery efficiency enhancement, and productivity branding influenced the deployment of ICTs in the industry.

The results of this study are also in line with the findings of Oyediran; Odusami (2005); Oladapo (2007); Ibironke et al. (2011) and Oyediran and Akintola (2011). Virus attack leading to data loss, lack of encouragement to invest in computers, cost of hiring computer experts, lack of management support to ICT, were among the factors responsible for the slow pace of 
DOI: 10.14807/ijmp.v11i4.1096

acceptance of ICT among construction professionals (OYEDIRAN; ODUSAMI, 2005; IBIRONKE et al., 2011).

According to Oladapo (2007), poor/insufficient power supply, high cost of engaging computer staff, lack of management desire and appreciation of ICT, security issues, low return on investment in ICT, high cost of hardware/software, fear of virus attack, high rate of obsolescence of software/hardware, personnel abuse, and fear of ICT making professionals redundant; were the major constraint to the acceptance of ICT facilities. Other factors considered as key in the decision to adopt technologies in construction are organisational and human issues (OYEDIRAN; AKINTOLA, 2011).

The finding of this study is in tandem with Usman et al. (2012), who reported that human factors which have to do with individuals, and the organisational culture are among the factors that influence the deployment of ICT by organisations. Human and management related concerns are among the crucial factors influencing the deployment of ICT facilities in construction as revealed in this study. Similarly, to Rezgui et al. (2004) highlighted issues relating to the legal ramifications of electronic communications, vague security framework, and issue of trust, as among the factors that influence the decision to deploy ICT by construction organisations.

\section{CONCLUSION AND RECOMMENDATIONS}

This study assessed the factors influencing the deployment of innovative information and communication technology (ICT) facilities by construction firms in Port Harcourt. The study adopted a survey design approach and was able to determine the factors influencing ICT deployment by construction firms were found.

Based on the findings, the study concludes that the factors influencing the deployment of innovative ICT by construction organisation ICT are change related issues, security related concerns, human and management related concerns, and cost related concerns. Key among these factors are satisfaction with existing method of working, inadequate trained ICT professionals inadequate knowledge about return on ICT investment, virus attack, security breach and fear of accuracy, and lack of legal support for use of ICT.

Based on the conclusion, the study, therefore, recommends that; stakeholders in the construction industry should embrace new ways of doing things. This will address over adherence to old traditional methods of operations. Adequate security of ICT infrastructures and facilities should be put in place. With this, fear of virus attack and loss of data and privacy 
DOI: 10.14807/ijmp.v11i4.1096

concerns would be resolved. For organisations to remain on top of its competitors, the management must create the enabling environment for innovation to thrive.

Therefore, management support is highly required for the deployment of ICT in the construction industry. Adequate budget should be made for the provision of ICT facilities, training of personnel and engagement of ICT specialist. Government who is the largest client of the construction industry should put legislation in place to make it mandatory for construction firms to make the use of ICT an integral part of their service delivery. This will create a legal base for the implementation of innovation ICT in construction activities.

With the continuous changes in technology and the need to exploit the immeasurable impact of innovative ICT on corporate businesses, this study, therefore, recommends that a future similar study be carried out on the factors that influence the ICT deployment in the Niger-delta region of Nigeria in which Port Harcourt is located. Also, similar study should be carried out to determine the impact of innovation ICT facilities deployment on the performance of construction organisation.

\section{REFERENCES}

AFOLABI, A.; IBEM, E.; ADUWO, E.; TUNJI-OLAYENI, P.; OLUWUNMI, O. (2019) Critical Success Factors (CSFs) for e-Procurement Adoption in the Nigerian Construction Industry. Buildings, v. 9, n. 47, p. 1-18.

AHADZIE, D. K.; PROVERBS, D. G.; OLOMOLAIYE, P. O. (2008) Critical success criteria for mass house building projects in developing countries. International Journal of Project Management, v. 26, p. 675-687.

AKINTOYE, A. (2000) Analysis of factors influencing project cost estimating practice. Construction Management and Economics, v.18, p. 77-89

ALABI, T. T.; ANIFOWOSE, O. M. (2018) Impact of Information and Communication Technology (Ict) Facilities Deployment on Quantity Surveying Practice in Abuja. In: JUNAID, A. M., ADEDAYO,O. F, JIMOH, R. A. AND OYEWOBI, L. O. (Eds) Proceedings of the School of Environmental Technology International Conference (SETIC) 2018. 10th - 12th April 2018, School of Environmental Technology, Federal University of Technology, Minna, Niger State, Nigeria.

ALAGHBANDRAD, A.; ASNAASHARI, E.; PREECE, C. (2012) Problems and barriers of ICT utilization on Iranian construction sites: Case study on the successful use of ICT in remote construction sites. Journal of Information Technology in Construction (ITcon), v.17, p. 93-102.

ALAGHBANDRAD, A.; NOBAKHT, M. B.; HOSSEINALIPOUR, M.; ASNAASHARI, E. (2011) ICT adoption in the Iranian construction industry: barriers and opportunities.

Proceedings of the $\mathbf{2 8}^{\text {th }}$ ISARC, Seoul, Korea, p. 280-285. 
ARIF, A. A.; KARAM, A. (2001) Architectural practices and their use of IT in the Western Cape Province, South Africa. Journal of Information Technology in Construction, v. 6, p. 17-34.

BETTS, M. (1999) Strategic management of IT in construction, Blackwell, Oxford, UK.

BLAXTER, L.; HUGES, C.; TIGHT, M. (2001) How to research, 2nd Edition, Open University Press, London, UK.

COSTELLO, A. B.; JASON O. (2005) Best practices in exploratory factor analysis: four recommendations for getting the most from your analysis. Practical Assessment Research \& Evaluation, v. 10, n. 7, Available online: http://pareonline.net/getvn.asp?v=10\&n=7

DENG, Z. M.; LI, H.; TAM, C. M.; SHEN, Q. P.; LOVE, P. E. D. (2001) An Application of Internet-based Project Management System, Automation in Construction, v.10, p. 239-246

ESSAYS, UK. (November 2018) ICT Developments In The Construction Industry. Retrieved from: https://www.ukessays.com/essays/information-technology/ict-developments-in-theconstruction-industry-information-technology-essay.php?vref=1

EZE, E. C.; IDIAKE, J. E.; GANIYU, B. O. (2018) Analysis of Rework Risk Triggers in the Nigerian Construction Industry. Organization, Technology and Management in Construction (OTMC), v. 10, n. 1, p. 1778-1793

EZE, E. C.; SOFOLAHAN, O.; ADEGBOYEGA, A. A.; SAIDU, K. J. (2019) Factors limiting the full-scale adoption of process and product innovation in the Nigerian construction industry. SEISENSE Journal of Management, v. 2, n. 3, p. 67-81.

FELLOWS, R. R.; LIU, A. (2008) Research Methods for Construction, 3rd Edition. Wiley- Blackwell Science, London.

FIELD, A. (2005) Discovering Statistics Using SPSS. 2nd Edition, Thousand Oaks, CA: Sage.

GAGNON, M.; DESMARTIS, M.; LABRECQUE, M.; CAR, J.; PAGLIARI, C.; PLUYE, P.; FREMONT, P.; GAGNON, J.; TREMBLAY, N.; LEGARE, F. (2012) Systematic review of factors influencing the adoption of information and communication technologies by healthcare professionals. Journal of Med System, v. 36, n. 1, p. 241-277.

GOH, B. H. (2005) IT barometer 2003: survey of the Singapore construction industry and a comparison of results. Journal of Information Technology in Construction, v. 10, p. 1-13.

HALIM, H. C. (2010) Assessment of the application of information and communication technology in real estate practice (A case study of Lagos metropolis). Published M.Sc. Thesis submitted to the Department of Estate Management, University of Nigeria, Enugu Campus.

HORE, A. V.; WEST, R. P. (2005) Attitudes towards electronic purchasing in the Irish construction industry. 2005 CIB W92/T23/W107 International Symposium on Procurement Systems, Las Vegas, USA.

IBIRONKE, O. T.; EKUNDAYO, D.; AWODELE, O. A. (2011) A survey on the use and impact of information technology in quantity surveying service delivery in Nigeria. In: 27th Annual ARCOM Conference, 5-7 September 2011, University of the West of England, Bristol, UK.

KAZAZ, A.; ULUBEYLI, S. (2009) Strategic management practices in Turkish construction firms. Journal of Management in Engineering, v. 25, n. 4, p. 185-194 
KOTHARI, C. R. (2004) Research Methodology; Methods and Techniques. 2nd Edition. New Delhi: New Age International.

LARYEA, S. (2010) Challenges and opportunities facing contractors in Ghana. In: Laryea, S., Leiringer, R. and Hughes, W. (Eds.) Procs West Africa Built Environment Research (WABER) Conference, 27-28 July 2010, Accra, Ghana, p. 215-226

LIM,Y. M.; RASHID, A. Z.; ANG, C. N.; WONG C. Y.; WONG, S. L. (2002) A survey of Internet usage in the Malaysian construction industry. Journal of Information Technology in Construction, v. 7, p. 259-269.

LISTON K. M.; FISCHER M. A.; KUNZ J. C. (2000) Designing and evaluating visualization techniques for construction planning. Proceedings of the 8th International Conference on Computing in Civil and Building Engineering (ICCCBE-VIII), Stanford University, Stanford, CA, 1293-300.

LÖFGREN, A. (2006) Mobile computing and project communication - mixing oil and water?, Licentiate thesis, Royal Institute of Technology, Stockholm.

MAQSOOD, T.; WALKER, D. H. T.; FINEGAN, A. D. (2004) An Investigation of ICT diffusion in an Australian construction contractor company using SSM. Proc. of the joint CIB-W107 and CIB-TG23 Symposium on Globalisation and Construction, Bangkok, Thailand, 17-19 November, p. 485-495.

MOHAMED, S.; STEWART, R. A. (2003) An empirical investigation of users' perceptions of web-based communication on a construction project. Automation in Construction, v. 12, p. 43-53.

MUNDFROM, D. J.; SHAW, D. G.; KE, T. L. (2005) Minimum sample size recommendations for conducting factor analyses. International Journal of Testing, v. 5, n. 2, p. $159-168$

MURRAY, M.; NKADO, R.; LAI, A. (2001) The integrated use of information technology in the construction industry. Proceedings of the CIB 78 Conference: IT in Construction in Africa, Pretoria, South Africa, 39-1 to 39-13.

MUTESI, E. T.; KYAKULA, M. (2011) Application of ICT in the construction industry in Kampala. Second International Conference on Advances in Engineering and Technology, p. 263-269

OLADAPO, A. A. (2007) An investigation into the use of ICT in the Nigerian construction industry. ITCON, v. 12, p. 261-277

ONYEAGAM, O. P.; EZE, E. C.; ADEGBOYEGA, A. A. (2019) Assessment of quantity surveying firms' process and product innovation drive in Nigeria. SEISENSE Journal of Management, v. 2, n. 2, p. 21-37

OYEDIRAN, O. S.; AKINTOLA, A. A. (2011) A survey of the state of the art of e-tendering in Nigeria. Journal of Information Technology in Construction, v. 16, p. 557-576

OYEDIRAN, O. S.; ODUSAMI, K. T. (2005) A study of computer usage by Nigerian quantity surveyors. Journal of Information and Technology in Construction, v. 10, p. 291-303.

OYETUNJI, A. K.; OJO, B.; OYETUNJI-OLAKUNMI, B. (2018) Factors influencing the deployment of ICT in Nigerian real estate practice. Journal of African Real Estate Research, v. 3, n. 1, p. 1-20. 
DOI: 10.14807/ijmp.v11i4.1096

PALLANT, J. (2005) SPSS Survival Manual: A step- by -step guide to data analysis using SPSS for windows (Version 12). 2nd Edition, Allen and Unwin, Crows Nest NSW 2065 Australia.

PALLANT, J. (2007) SPSS Survival Manual: A step-by-step guide to data analysis using SPSS (version 15), 3rd edition, Open University Press, England.

PEANSUPAP, V.; WALKER, D. H. T. (2005) Factors enabling information and communication technology diffusion and actual implementation in construction organisations, ITcon, v. 10, p. 193-218.

PEANSUPAP, V.; WALKER, D. H. T. (2006) Innovation diffusion at the implementation stage of a construction project: a case study of information communication technology.

Construction Management and Economics, v. 24, n. 3, p. 321-332

REZGUI, Y.; WILSON, I. E.; DAMODARAN, L.; OLPHERT, W.; SHILBOUM, M. (2004) ICT adoption in the construction sector: Education and training issues”. Retrieved 10.04.2019 from http://e-pub.uni-weimar.de/volltexte/

RIVARD, H. (2000) A survey on the impact of information technology in the Canadian architecture, engineering and construction industry. Journal of Information Technology in Construction, v. 5, p. 37-56.

SAMUELSON, O. (2002) IT-Barometer 2000 - the use of IT in the Nordic construction industry. Journal of Information Technology in Construction, v. 7, p. 1-26.

SARCHAR, M.; ISIKDAG, U. (2004) A survey of ICT use in the Turkish construction industry. Engineering, Construction and Architectural Management (ECAM), v. 11, n. 4, p. 238-247.

SEKOU, E. A. (2012) Promoting the use of ICT in the construction industry: assessing the factors hindering usage by building contractors in Ghana. Msc Thesis, Kwame Nkrumah University of Science and Technology-Kumasi,Ghana

SHARMA, S. (1996) Applied Multivariate Techniques. John Wiley and Sons, Inc., New York

SHOESMITH, D. R. (1995) Using internet as a dissemination channel for construction research. Construction Information Technology, v. 3, n. 2, p. 65-75

SPECTOR, P. (1992) Summated rating scale construction: an introduction. Newbaury Park, California: Sage Publications.

STERN, L. (2010) A visual approach to SPSS for Windows: a guide to SPSS 17.0. 2nd ed., Boston: Allyn and Bacon

TABACHNICK, B. G.; FIDELL, L. S. (2007) Using multivariate statistics. 5th Ed. Pearson Education Inc.

TAKIM, R.; ADNAN, H. (2008) Analysis of effectiveness measures of construction project success in Malaysia. Asian Social Science Journal, v. 4, n. 7, p. 75-89

TOOLE T. M. (2003) Information technology innovation: a view of large contractors. Proceedings of the ASCE Construction Research Congress, Honolulu, Hawaii, at http://www.facstaff.bucknell.edu/ttoole/ITinnovation.doc

UGWUANYI, D. C.; UGWU, O. O. (2015) The impact of information and communication technology (ICT) application in Nigerian construction industry. NJISS, v. 12, n. 1, p. 1-16. 
USMAN, N.; SAID, I.; YAHAYA, A. Z. (2012) Indolent disposition towards ict acceptance among practising quantity surveyors in Nigeria. Acta Technica Corviniensis - Bulletin of Engineering, v. 2, p. 75-80.

WAZIRI, A. Y.; MUSTAPHA, Y. KATUN M. I. (2017) A Theoretical model of factors influencing it adoption in Nigerian construction organizations. International Journal of Engineering and Technology (IJET), v. 9, n. 3, p. 1809-1815

WOKSEPP, S.; OLOFSSON, T. (2006) Using virtual reality on a large-scale industry project. ITCon Electronic Journal of Information Technology in Construction, v. 11, p. 627-640

YONG, G.; PEARCE, S. (2013) A beginner's guide to factor analysis: Focusing on exploratory factors Analysis. Tutorials in quantitative Methods for Psychology. v. 9, n. 2, p. 79-94. 